\title{
Biases in CMIP5 Sea Surface Temperature and the Annual Cycle of East African Rainfall
}

\author{
BRADFIELD LYON \\ Climate Change Institute and School of Earth and Climate Sciences, University of Maine, Orono, Maine
}

(Manuscript received 12 February 2020, in final form 1 July 2020)

\begin{abstract}
In much of East Africa, climatological rainfall follows a bimodal distribution characterized by the long rains (March-May) and short rains (October-December). Most CMIP5 coupled models fail to properly simulate this annual cycle, typically reversing the amplitudes of the short and long rains relative to observations. This study investigates how CMIP5 climatological sea surface temperature (SST) biases contribute to simulation errors in the annual cycle of East African rainfall. Monthly biases in CMIP5 climatological SSTs $\left(50^{\circ} \mathrm{S}-50^{\circ} \mathrm{N}\right)$ are first identified in historical runs (1979-2005) from 31 models and examined for consistency. An atmospheric general circulation model (AGCM) is then forced with observed SSTs (1979-2005) generating a set of control runs and observed SSTs plus the monthly, multimodel mean SST biases generating a set of "bias" runs for the same period. The control runs generally capture the observed annual cycle of East African rainfall while the bias runs capture prominent CMIP5 annual cycle biases, including too little (much) precipitation during the long rains (short rains) and a 1-month lag in the peak of the long rains relative to observations. Diagnostics reveal the annual cycle biases are associated with seasonally varying north-south- and east-westoriented SST bias patterns in Indian Ocean and regional-scale atmospheric circulation and stability changes, the latter primarily associated with changes in low-level moist static energy. Overall, the results indicate that CMIP5 climatological SST biases are the primary driver of the improper simulation of the annual cycle of East African rainfall. Some implications for climate change projections are discussed.
\end{abstract}

\section{Introduction}

Across East Africa (study domain shown in Fig. 1) climatological rainfall shows considerable heterogeneity, although for much of the region it follows a bimodal annual cycle as evidenced by the long rains of MarchMay (MAM; other seasons denoted similarly) and the short rains during OND. The bimodal rainfall distribution is related to the meridional translation of the intertropical convergence zone across the equator, with topography further influencing rainfall locally (Hession and Moore 2011; Nicholson 1996). Further, the long rains typically undergo a meridional "jump" of several degrees of latitude during MAM as low-level southerly flow develops off the equatorial east coast (Riddle and Cook 2008) concurrent with the development of the Findlater jet, itself tied to the north-south orientation of East African orography (Vizy and Cook 2003; Hart 1977; Findlater 1969). Based on a moist static energy

\footnotetext{
Corresponding author: Bradfield Lyon, bradfield.lyon@maine. edu
}

(MSE) framework, Yang et al. (2015a) showed a close correspondence between the annual cycles of East African rainfall and sea surface temperatures (SSTs) in the western Indian Ocean. Observed SSTs peak in that location during April, concomitant with the peak of the long rains, and subsequently cool in association with the development of the South Asian summer monsoon circulation, the latter contributing to a reduced, secondary maxima in both SST and rainfall during OND.

Given these complexities it is perhaps understandable that global climate models struggle to properly simulate the climatological annual cycle of East African rainfall. Previous studies have shown this is indeed the case, with most models from phase 5 of the Coupled Model Intercomparison Project (CMIP5) having the tendency to generate too much rainfall in the OND short rains and too little in the MAM long rains relative to observations (Lyon and Vigaud 2017; Yang et al. 2015b; Otieno and Anyah 2013). In addition to their fairly coarse spatial resolution (e.g., relative to topographic variations in East Africa), coupled climate models are known to exhibit systematic biases, including biases in their climatological 


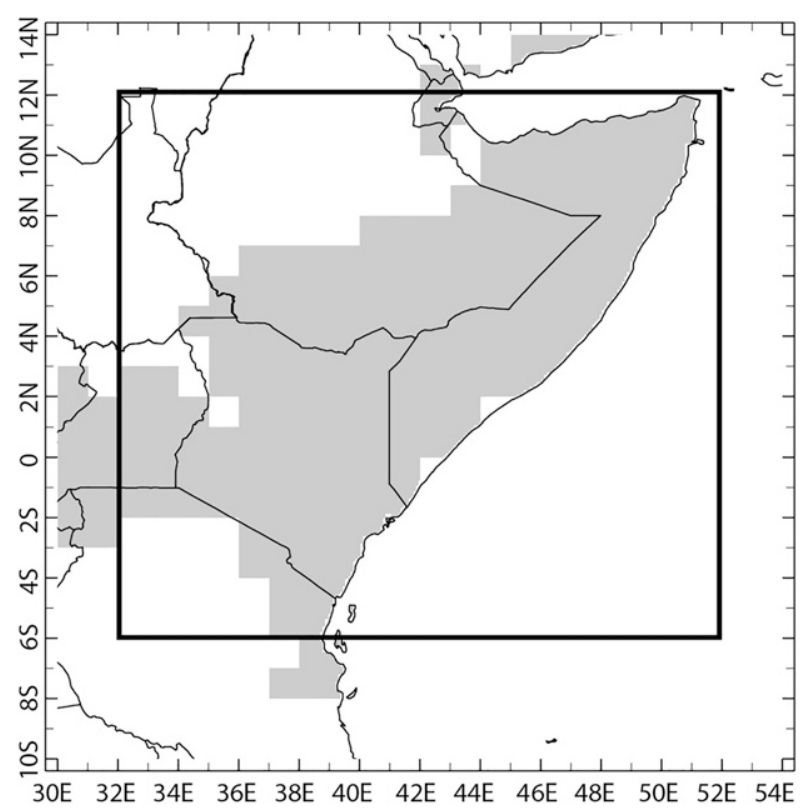

FIG. 1. Overall study domain indicated by black box. Gray shading indicates locations with a bimodal rainfall distribution that are used in the analysis.

SSTs. An important example of relevance to East African climate is the general failure of coupled models to capture the observed annual cycle of SSTs in the western equatorial Indian Ocean, tending to be too warm in the boreal fall and too cool during boreal spring (Lyon and Vigaud 2017; Yang et al. 2015b). Yang et al. (2015b, hereafter Y15) examined CMIP5 model errors in simulating the observed annual cycle of East African rainfall but emphasized differences in behavior between a single coupled model and its atmospheric model component. They found that differences in the surface temperature field (equivalent to SST over the ocean) between the coupled and atmospheric models were associated with errors in simulating climatological rainfall in East Africa. Y15 undertook various diagnostic analyses to identify physical mechanisms associated with both the East African rainfall bias in this model and the generation of the SST biases themselves.

This study extends the analysis of Y15 by examining 1) the climatological SST biases in 31 CMIP5 coupled models, 2) the consistency of these biases across the models, and 3) the atmospheric response to the multimodel mean SST bias in an atmospheric general circulation model (AGCM). The main goal of the study is to examine the extent to which the biases in CMIP5 climatological SSTs can be related to coupled model biases in simulating the annual cycle of East African climatological rainfall. Thus, the atmospheric response to coupled model SST biases is emphasized rather investigating the physical mechanisms responsible for the generation of the SST biases. Here, after computing the monthly climatological SST biases in each model (and comparing biases across the models), the multimodel mean SST biases are added to observed monthly SSTs (1979-2005) with the combination used as the lower boundary forcing in the ECHAM5 AGCM (Roeckner et al. 2003). An ensemble of ECHAM5 SST "bias" runs is generated, with the output compared to both CMIP5 model output and a set of ECHAM5 control runs, where in the latter case the model is forced with observed SSTs. In addition to examining the influence of CMIP5 SST biases on the annual cycle of East African rainfall, associated changes in the regional atmospheric circulation are evaluated as well as changes in local atmospheric stability through the annual cycle.

Whereas variations in CMIP5 simulations of climatological rainfall in East Africa may be influenced by different model formulations, spatial resolutions, and various parameterizations, here the influence of CMIP5 SST biases alone is evaluated by examining the atmospheric response to those biases in a single AGCM. To the extent that the ECHAM5 captures the observed annual cycle of climatological rainfall in East Africa and responds properly to SSTs generally, the results of the study will indicate the potential impact CMIP5 SST biases play in generating coupled model biases in the simulation of East African climatological rainfall.

The paper is organized as follows. The observational and climate model data used in the study are described in section 2 along with a description of the basic methodological approach. CMIP5 biases in the annual cycle of East African rainfall and climatological SSTs are discussed in section 3. The annual cycle of East African rainfall in the ECHAM5 bias and control runs is compared with observations and CMIP5 historical simulations in section 4 where changes in the regional atmospheric circulation and local atmospheric stability conditions are also considered. A summary of the overall findings and the main conclusions drawn from the study are reported in section 5 .

\section{Data and methodology}

\section{a. Observational and model data}

Several monthly, gridded precipitation analyses were utilized, which primarily cover the period 1979-2005 unless otherwise noted. The base period 1979-2005 was chosen primarily because the CMIP5 historical runs end in 2005 and the starting year of 1979 allowed for a robust estimate of climatological rainfall while avoiding the additional computational costs associated with using a 
longer base period when generating the atmospheric model runs needed for the study. The specific observational datasets include the Global Precipitation Climatology Center (GPCC v7) product based on gauge observations, and gridded to $1.0^{\circ}$ latitude/longitude resolution (Rudolf and Rubel 2005); the gauge-based version TS 4.01 of monthly precipitation over global land areas from the Climatic Research Unit at the University of East Anglia (CRU; Harris and Jones 2017) gridded to $0.5^{\circ}$ latitude/ longitude resolution; version 2.3 of the Global Precipitation Climatology Project (GPCP) monthly precipitation dataset (Huffman et al. 2009), which combines satellite estimates with gauge observations and is gridded to a $2.5^{\circ}$ latitude/ longitude resolution; version 2.0 of the monthly Climate Prediction Center (CPC) Merged Analysis of Precipitation (CMAP; Xie and Arkin 1997), which also combines satellite and gauge data and is gridded to a $2.5^{\circ}$ latitude/ longitude resolution; version 2.0 of the Climate Hazards Group Infrared Precipitation with Station data (CHIRPS; Funk et al. 2015) covering the period 1981-2005 and gridded to a $0.05^{\circ}$ latitude/longitude resolution; and version 1.1 of the satellite-based Precipitation Estimation from Remotely Sensed Information using Artificial Neural Networks (PERSIANN; Ashouri et al. 2015) data covering the period 1983-2005 and gridded to a $0.25^{\circ}$ latitude/longitude spatial resolution.

Monthly SST analyses from the Extended Reconstructed SST dataset (ERSST v4) were employed (Huang et al. 2015). These data are gridded to a $2.0^{\circ}$ latitude/longitude resolution with data for the period 1977-2005 used in the study, both for diagnostic analysis and for forcing the ECHAM5 atmospheric model. Output from 31 coupled models contained in the CMIP5 archive (Taylor et al. 2012) were employed (a listing of the models is found in the appendix). CMIP5 variables included monthly average values of surface temperature (equivalent to SST over ocean areas), precipitation, and atmospheric temperature, specific humidity, geopotential height, and vector wind components at different pressure levels. Model precipitable water was also examined.

\section{b. Methodological approach}

To identify locations in the East African domain with a bimodal rainfall annual cycle, the GPCC monthly climatological rainfall (1981-2000) was used to mask grid points where JF (JJA) rainfall exceeded 1/4 (1/3) of the annual average total value. This masks areas such as western Ethiopia and northern Tanzania, for example, where climatological rainfall is generally more unimodal. The resulting analysis domain is shown by the shaded region in Fig. 1. In the subsequent analyses, various observations and climate model results are averaged over this shaded region, which hereafter will simply be called East Africa. As will be shown, and consistent with previous work (Yang et al. 2015a; Lyon 2014), the GPCC data do a good job capturing the annual cycle of rainfall across East Africa and, thus, regions of bimodality.

CMIP5 SST biases were identified in each of the 31 models by first computing monthly, climatological values of the surface temperature (variable .ts) from historical runs made with all known natural and anthropogenic forcing for the period 1979-2005. Once obtained, each model's monthly SST climatology was regridded to a $2.0^{\circ}$ latitude/longitude resolution to match the resolution of observed SSTs (from ERSST). Land areas were omitted from the analysis. Monthly CMIP5 SST biases were computed for each model by subtracting the observed monthly climatology (19792005) from the model climatology. As a test, it was found in a subset of five randomly selected models that the difference in the annual average, absolute SST bias computed over 1950-2005 versus 1979-2005 was about $0.1^{\circ} \mathrm{C}$ when averaged over $50^{\circ} \mathrm{S}-50^{\circ} \mathrm{N}$, indicating the results presented here are not likely to be overly sensitive to the base period used to compute the bias. For use in this study, the multimodel mean climatological SST bias was also computed for each month. An empirical orthogonal function (EOF) analysis applied to seasonal SST biases (DJF, MAM, JJA, SON; $50^{\circ} \mathrm{S}-50^{\circ} \mathrm{N}$ ) across the models showed that for each season, all 31 models projected onto the leading EOF pattern for that season (not shown). Using rotated EOFs provided very similar results. In addition, the loading patterns of the leading EOF (either unrotated or rotated) for each season were found to be very similar to the multimodel mean SST bias pattern for each season (not shown). Thus, the multimodel mean bias is considered generally representative of individual model bias patterns (more information on this aspect is provided in section 3). It is also noted that there tends to be a slightly negative, though not statistically significant, relationship between the absolute value of model SST bias averaged across the tropics and the correlation between the modeled and observed annual cycle of East African climatological rainfall (not shown). In other words, generally speaking, there is a weak tendency for higher model SST bias to be associated with poorer model performance in simulating observed East African rainfall.

To examine the atmospheric response to CMIP5 climatological SST biases, the ECHAM5 AGCM was utilized. Previous studies (e.g., Lyon and Vigaud 2017; Liebmann et al. 2014) have shown the ECHAM5 AGCM does a generally good job simulating East African climate and reproducing observed associations between East African rainfall and SSTs. More generally, 


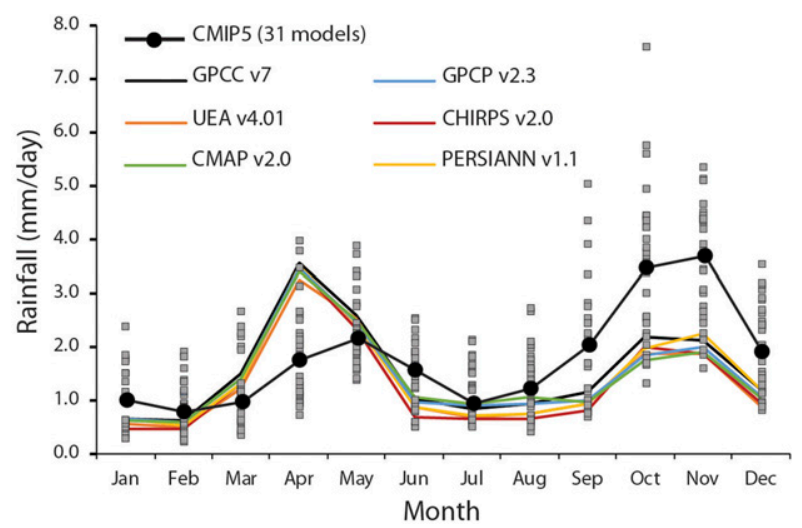

FIG. 2. Climatological monthly rainfall $\left(\mathrm{mm} \mathrm{day}^{-1}\right)$ for the shaded region in Fig. 1. The thick black line is the median value of the 31 CMIP5 simulations, with individual model values shown by the gray points. The colored lines are the annual cycle from six observational datasets. The base period for both observations and models is 1979-2005, with the exception of CHIRPS (1981-2005) and PERSIANN (1983-2005).

earlier work by Yang et al. (2015b) showed that when the atmospheric component of coupled climate models is forced with observed SSTs (i.e., AMIP-style run) their simulation of the East African annual rainfall cycle generally has a higher correlation with observations (and lower root-mean-square error) than the corresponding coupled versions of the models do. The ECHAM5 AGCM is a spectral model, configured in this study with a triangular truncation at wavenumber 42 (T42; spatial resolution of roughly $2.8^{\circ}$ latitude $\times$ longitude) with 19 unevenly spaced hybrid sigma-pressure vertical layers (Simmons and Burridge 1981). Sea ice concentrations are prescribed and derived from the observational surface boundary forcing dataset for uncoupled simulations with the Community Atmosphere Model based on Hurrell et al. (2008) that is a merged product of the monthly mean Hadley Centre sea ice and SST dataset version 1 (HadISST1; Rayner et al. 2003) and version 2 of the NOAA weekly optimum interpolation (OI) SST analysis (Reynolds et al. 2002). Greenhouse gas concentrations are kept at the year 2000 values and no aerosol forcing is used. This is the same model formulation as recently described in Vigaud et al. 2020). Two sets of model runs were generated for use in the study. First, a set of ECHAM5 control runs was made by forcing the model with observed, monthly SSTs from ERSST v4 for the period 1977-2005. The SST forcing for a second set of ECHAM5 "bias" runs consisted of the combination of monthly, multimodel mean CMIP5 climatological SST biases $\left(50^{\circ} \mathrm{S}-50^{\circ} \mathrm{N}\right)$ and the observed monthly SSTs. In both the control and bias runs, the monthly average value of the SST field was treated as a midmonth value with daily SST values obtained by linearly interpolating between these midmonth values (i.e., across months). These interpolated, daily SST values were used as the SST forcing field in the model. To avoid adding or removing heat from the climate system (relative to the control runs) the global average, multimodel mean SST bias was first subtracted from the multimodel mean SST bias field at each grid point before combining with observed SSTs. A 16member ensemble was generated for both sets of runs by using initial atmospheric conditions that differed by one day in each model run, starting on 1 January 1977. The ECHAM5 output was analyzed for the period 19792005 (instead of 1977-2005) to avoid any spinup issues. Using an overbar to represent the monthly climatological mean and a prime to denote the monthly departure from that mean, the SST forcing for the control (ctrl) and bias runs may be written, respectively, as

$$
\begin{aligned}
\mathrm{SST}_{\mathrm{ctrl}} & =\overline{\mathrm{SST}}_{\mathrm{obs}}+\mathrm{SST}_{\mathrm{obs}}^{\prime}, \quad \text { and } \\
\mathrm{SST}_{\text {bias }} & =\overline{\mathrm{SST}}_{\mathrm{obs}}+\overline{\mathrm{SST}}_{\mathrm{bias}}+\mathrm{SST}_{\mathrm{obs}}^{\prime} .
\end{aligned}
$$

Differences between bias and control run values of various quantities were tested for statistical significance using a two-tailed $t$ test.

\section{CMIP5 climatological biases: East African rainfall and SSTs}

Monthly climatological rainfall averaged across East Africa is shown in Fig. 2 for both observations and the CMIP5 models. For observations, monthly rainfall is shown for six different datasets, which show very strong agreement with one another. For the models, the median monthly rainfall amount computed across the models is shown along with the monthly value for each model. It is found that 29/31 models (93\%) have OND rainfall that exceeds that in MAM and in 22/31 models (71\%) May rainfall exceeds that in April. The variance in monthly average rainfall across the models generally increases with increasing median monthly rainfall amount (the correlation between the two being $r=0.9$ ). Averaged across all months of the year, 22/31 models (71\%) have monthly climatological rainfall that differs by less than $50 \%$ of the multimodel median value. Overall, the key findings are that CMIP5 models tend to generate too little rainfall during the MAM long rains and too much in the OND short rains relative to observations, and there is typically a 1-month delay in the peak of the MAM long rains in the models compared to observations. In the analyses that follow, these CMIP5 model precipitation biases are related to biases in CMIP5 climatological SSTs. 

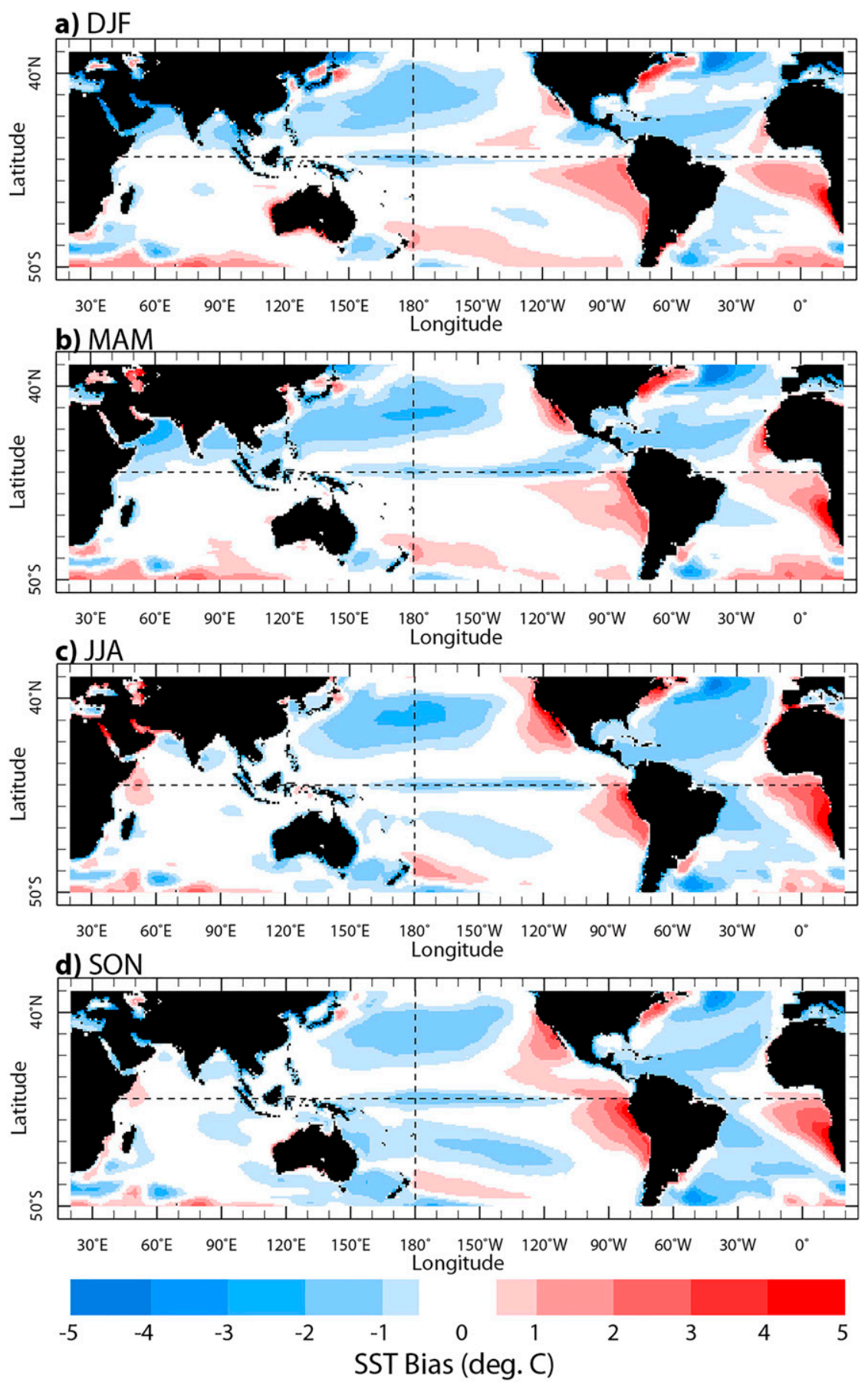

FIG. 3. Multimodel mean CMIP5 bias $\left({ }^{\circ} \mathrm{C}\right)$ in climatological SST (1979-2005) by season.

The CMIP5 multimodel mean SST biases for DJF, MAM, JJA, and SON are shown in Fig. 3. In the tropics, the CMIP5 models generally underestimate the cooling in major coastal upwelling regions (Yang et al. 2015a) and they extend the equatorial Pacific cold tongue too far to the west (e.g., Li and Xie 2014, 2012). In the equatorial Atlantic, coupled models tend to generate a zonal gradient in SSTs that is often of the wrong sign (Richter et al. 2014; Xu et al. 2014; Tozuka et al. 2011) while underestimating the upwelling strength along the Benguela coast (Xu et al. 2014) in the southeast portion of the basin. 

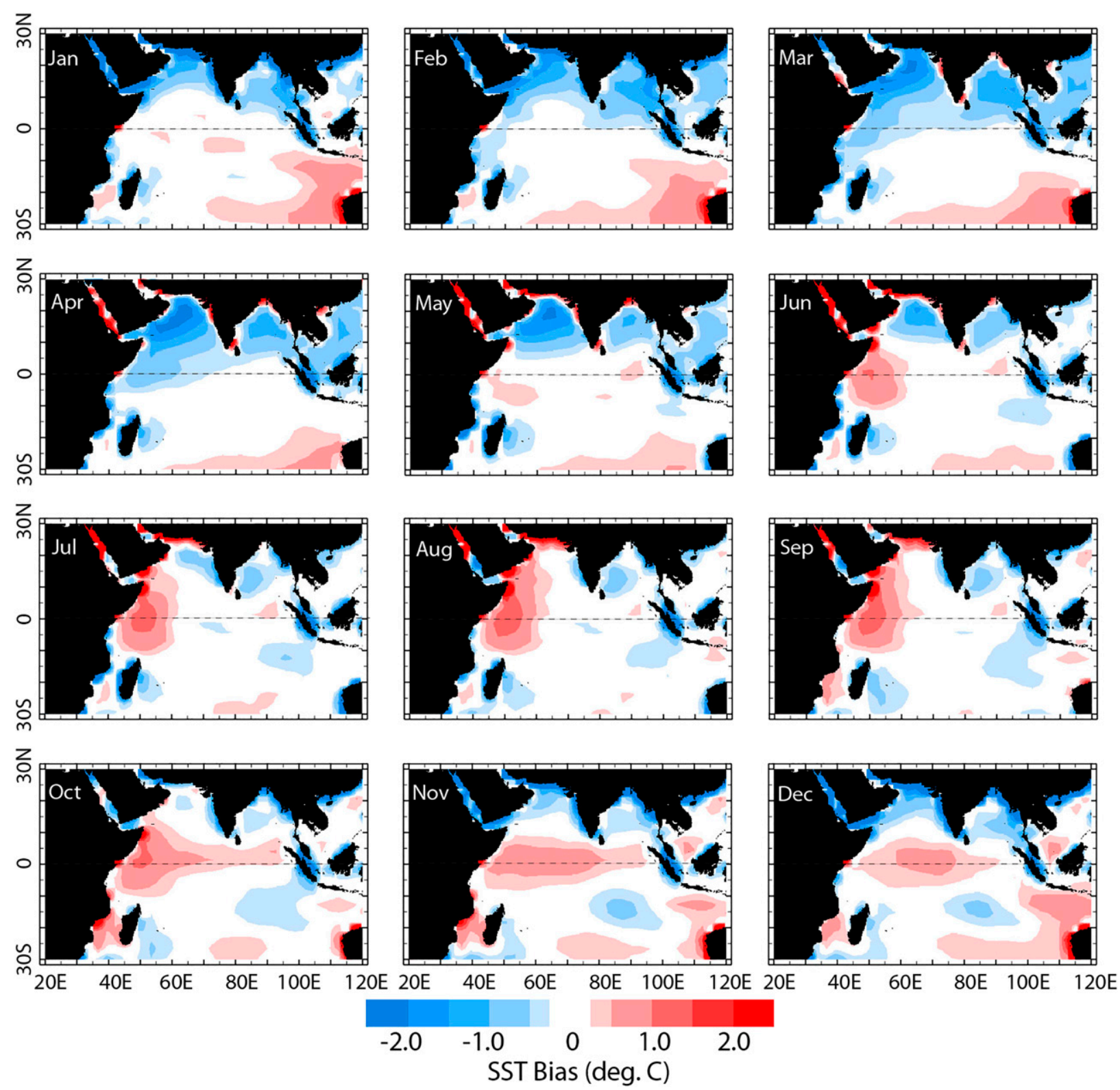

FIG. 4. As in Fig. 3, but showing monthly values for the Indian Ocean.

The CMIP5 monthly climatological SST biases for just the Indian Ocean are shown in Fig. 4. Note the different color scale from that used in Fig. 3, as the magnitude of the SST biases tends to be smaller in the Indian Ocean than other basins. It is not clear why this is the case, although globally, positive SST biases tend to be larger in magnitude than negative biases and are typically associated with cold current, upwelling regions along the west coasts of continents (the positive biases along the northeast coast of North America are likely related to improper modeling of the Labrador Current and Gulf Stream). The CMIP5 models generally exhibit an easterly wind bias over the equatorial portion of the Indian Ocean (Cai et al. 2013), resulting in enhanced shoaling of the thermocline in the eastern portion of the basin and thus a negative SST bias through much of the year. The western equatorial Indian Ocean tends to be too warm during the boreal summer and fall, while the northern portion of the basin tends to be too cold relative to observations from winter into boreal spring (Lyon and Vigaud 2017). A general north-south gradient in SST bias is seen from January into boreal spring in May.

The consistency of the CMIP5 climatological SST biases across the 31 models was examined by computing 


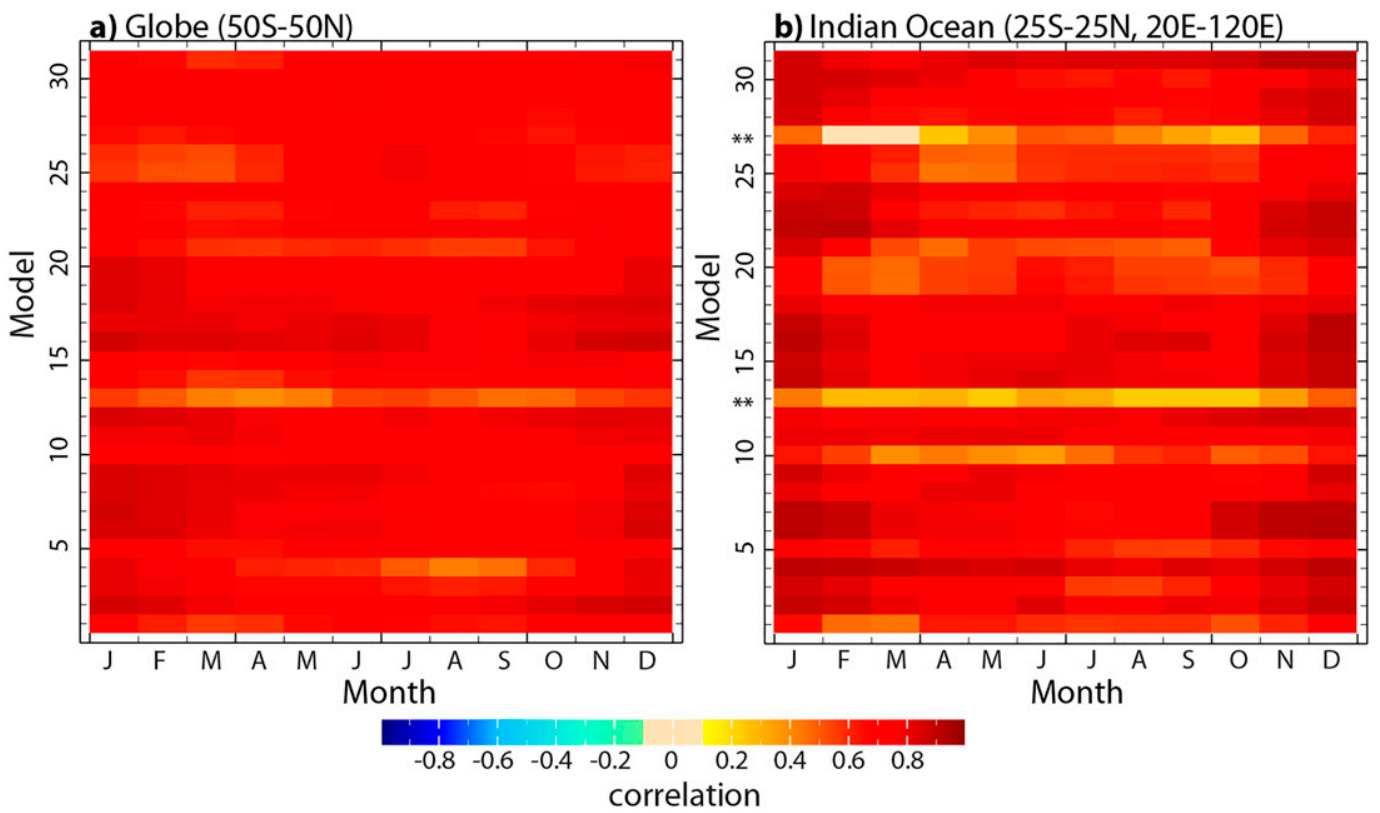

FIG. 5. Pattern correlation between the CMIP5 multimodel mean SST bias and the bias of individual models, by month. (a) The near-global domain $\left(50^{\circ} \mathrm{S}-50^{\circ} \mathrm{N}\right)$, and (b) the Indian Ocean region $\left(25^{\circ} \mathrm{S}-25^{\circ} \mathrm{N}, 20^{\circ}-120^{\circ} \mathrm{E}\right)$. Asterisks in (b) identify two models discussed further in the text.

the pattern correlations between the monthly multimodel mean bias and the monthly bias in individual models. These pattern correlations were computed for the near-global domain $\left(50^{\circ} \mathrm{S}-50^{\circ} \mathrm{N}\right)$ and the tropical Indian Ocean $\left(25^{\circ} \mathrm{S}-25^{\circ} \mathrm{N}, 20^{\circ}-120^{\circ} \mathrm{E}\right)$ with the results shown in Fig. 5. It is noted that omitting the interior southern Indian Ocean $\left(25^{\circ} \mathrm{S}-0^{\circ}, 60^{\circ}-100^{\circ} \mathrm{E}\right)$ where SST biases are generally smaller (cf. Fig. 4) had little influence on the overall results. For both spatial domains the pattern correlations are positive for all models and for all calendar months, with values exceeding 0.6 at $>91 \%$ $(>79 \%)$ of all model months for the near-global domain (Indian Ocean). For the Indian Ocean, two models in Fig. 5b have pattern correlations substantially lower than other models (marked with asterisks). This point will be returned to in subsequent analyses.

\section{ECHAM5 comparisons with CMIP5 historical simulations}

\section{a. East African climatological rainfall in ECHAM5 and $C M I P 5$}

The monthly, climatological average rainfall for East Africa for the ensemble mean of the ECHAM5 bias and control runs is shown in Fig. 6. Also shown in the figure are climatologies for observations (GPCC) and the CMIP5 multimodel mean. The ECHAM5 control runs do a generally good job in capturing East Africa's bimodal rainfall climatology, including greater rainfall amounts during the MAM long rains than in the OND short rains. ECHAM5 does generate more rainfall than observed in DJF, but the temporal correlation with the observed annual cycle is $r=0.85$. The ECHAM5 bias runs reverse the relative amplitudes of the long and

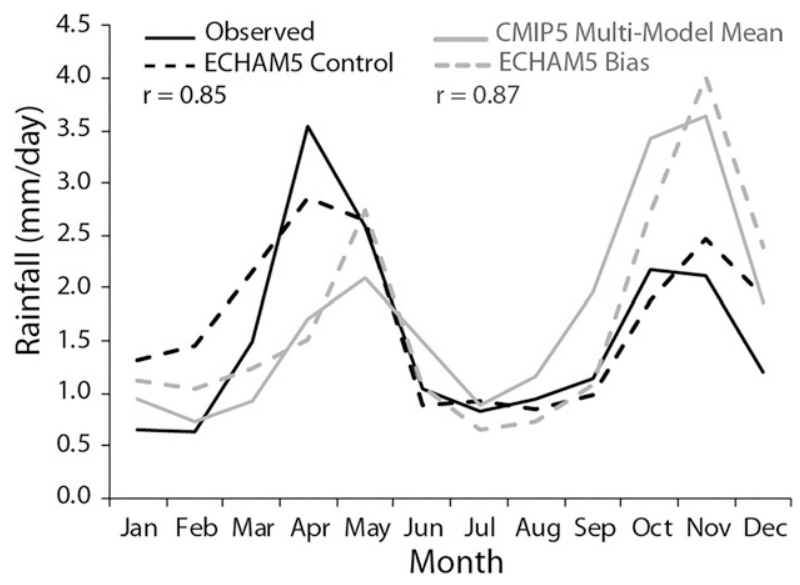

FIG. 6. Monthly climatological East African rainfall (mm day ${ }^{-1}$ ) in observations (GPCC; solid black line), ensemble mean of ECHAM5 control runs (dashed black line), CMIP5 historical simulations multimodel mean (solid gray line), and ensemble mean of ECHAM5 bias runs (dashed gray line). The temporal correlations between pairs of time series are shown near the top of the plot. 


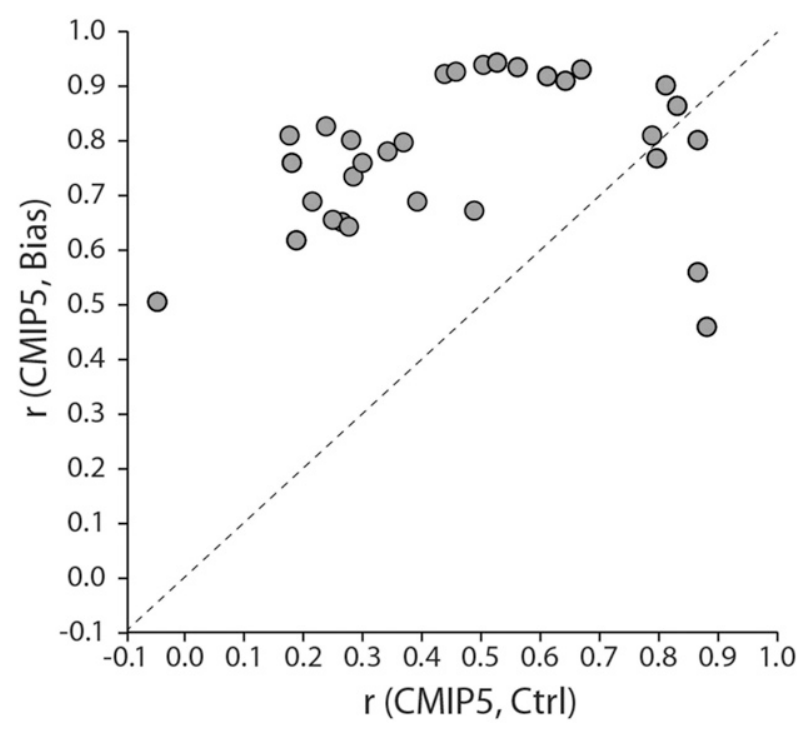

FIG. 7. Temporal correlation of monthly climatological rainfall in East Africa between individual CMIP5 models and the ensemble mean of ECHAM5 bias runs (vertical axis) and control runs (horizontal axis).

short rains, generating too much rainfall in OND compared to MAM. In addition, the bias runs climatology shows a long rains peak in May rather than in April, as observed. As such, the rainfall climatology from the ECHAM5 bias runs is quite similar to the that of the CMIP5 historical simulations, with the temporal correlation between those two climatologies being $r=0.87$. These results strongly suggest that the coupled models' inability to properly capture the rainfall annual cycle in East Africa is tied to their biases in climatological SST.

To examine how consistent the CMIP5 multimodel mean results of Fig. 6 are across individual CMIP5 models, temporal correlations were computed between the climatological annual cycle of East African rainfall in each model and, separately, that in the ECHAM5 bias and control runs ensemble means. The expectation is that the correlations will be higher between CMIP5 and the ECHAM5 bias runs rather than with the ECHAM5 control runs. The correlation pairs are plotted for each CMIP5 model in Fig. 7, which shows most of the CMIP5 models behave as expected (i.e., the points are above the diagonal line in the figure). While 4 of the 31 CMIP5 models show a stronger correlation with the annual cycle in the ECHAM5 control runs, only 2 CMIP5 models show substantial departures in this regard. These two CMIP5 models are marked with an asterisk in Fig. 5b, with that figure showing that their climatological SST biases had the lowest pattern correlation with the 31model mean SST bias pattern. This result would be expected if SST biases are indeed tied to CMIP5 errors in simulating the East African rainfall climatology.

\section{b. ECHAM5 regional atmospheric circulation response, association with SST bias patterns}

To explore the influence of the CMIP5 SST biases on regional atmospheric conditions, differences (bias control) in ensemble mean values of ECHAM5 rainfall and the $850-\mathrm{hPa}$ vector wind were computed, with the results shown in Fig. 8 as a function of season. During JF, anomalous northerly 850 -hPa flow is seen off the coast of East Africa north of the equator with anomalous westerlies near the equator to about $10^{\circ} \mathrm{S}$, which is generally consistent with an anomalously cool Arabian Sea and warmer SST conditions farther south (cf. Fig. 4). Bias minus control differences in East African rainfall during JF are relatively small, with enhanced rainfall seen over the west-central Indian Ocean. During MAM, East Africa is anomalously dry, with anomalous northeasterly flow off the East African coast and anomalous easterlies over the northern Indian Ocean opposing the observed climatological winds during this transition season ahead of the South Asian monsoon. This is consistent with a delay in the annual cycle of the regional atmospheric circulation as well as East African rainfall (recall the CMIP5 simulations and ECHAM5 bias runs both show the East African long rains peaking in May rather than April, as observed). For JJAS, the anomalous low-level winds generally oppose the observed monsoon flow over the northern Indian Ocean, with anomalously dry conditions over northern portions of the basin. The CMIP5 multimodel mean SST bias during this season transitions to a more east-west pattern, with anomalously high SSTs off of the East African coast (Fig. 4) in response to the CMIP5 models' inability to capture the cooling associated with the Somali jet. During OND, the anomalous $850-\mathrm{hPa}$ flow now reinforces the climatological northeast monsoon flow, increasing precipitation in East Africa and over the western equatorial Indian Ocean where SSTs remain anomalously warm (Fig. 4).

The ECHAM5 model has the tendency to overestimate rainfall in the southwestern equatorial Indian Ocean (e.g., Bollasina and Ming 2013) and East African rainfall in the model may respond a bit too strongly to western Indian Ocean SSTs relative to observations (Liebmann et al. 2014). However, here the difference between bias and control runs in ECHAM5 is emphasized, which should reduce these issues. Caveats aside, the results indicate that the CMIP5 annual cycle bias in East African rainfall is tied to regional-scale changes in the seasonal monsoon systems, which are themselves tied only to climatological biases in CMIP5 SSTs. Based on a coupled model ocean heat budget analysis, Y15 argued that a similar low-level flow that opposes the 

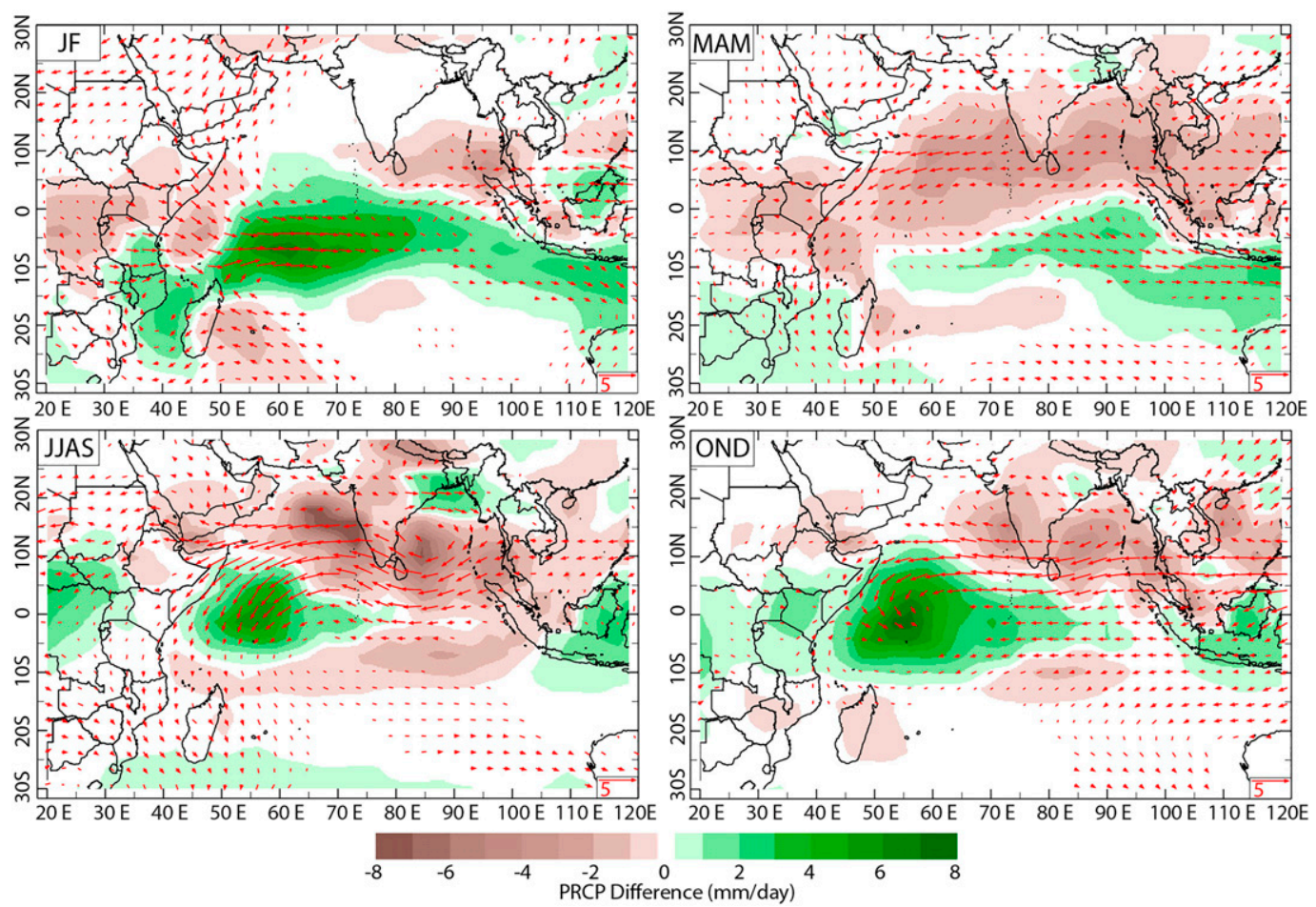

FIG. 8. Differences in ensemble mean, climatological precipitation (shading; $\mathrm{mm} \mathrm{day}^{-1}$ ), and $850-\mathrm{hPa}$ wind (vectors) between the ECHAM5 bias runs and control runs for different seasons. Representative wind vectors $\left(\mathrm{m} \mathrm{s}^{-1}\right)$ are shown at the lower right of each panel. Only differences that are statistically significant $(p<0.05)$ are plotted (at least one wind vector component).

Asian summer monsoon circulation is likely a response, rather than the cause, of the positive SST bias that develops off the East African coast during boreal spring/ summer. That conclusion is consistent with the ECHAM5 response to SST biases shown here in Fig. 8.

Recall that in four CMIP5 models, the climatological annual cycle in East African rainfall was more highly correlated with the ECHAM5 control runs than the bias runs (Fig. 7), indicating these CMIP5 models had a more realistic annual cycle than the other models. For these four models the climatological $850-\mathrm{hPa}$ vector wind and SST bias was compared with the corresponding average values from the other 27 models ( 31 models total). The average differences for these four models are shown in Fig. 9 for the MAM and OND seasons. For MAM, the anomalous 850-hPa flow over the western Indian Ocean is now southwesterly, with the northern portion of the basin warmer than in the south, the opposite of the 31 multimodel mean bias. These conditions are consistent with enhanced MAM rainfall in East Africa during this season relative to the other CMIP5 models. For OND the SST difference pattern is more zonal, with the eastern equatorial Indian Ocean warmer than the west with anomalous westerlies near the equator. An anomalous southwesterly flow is seen off the East African coast. These conditions would act to reduce OND rainfall over East Africa, being somewhat akin to the negative phase of the Indian Ocean dipole (IOD) and making this season's component of the annual cycle of East African rainfall more realistic.

\section{c. Physical considerations of changes in the East African rainfall annual cycle}

Yang et al. (2015a) used a moist static energy (MSE) framework in their analysis of the climatological annual cycle of East African rainfall. Among other findings, the study showed the modulating influence of western Indian Ocean SSTs on convective instability, primarily through changes in low-level atmospheric moisture content. In addition to western Indian Ocean SSTs alone, previous studies have shown the equatorial zonal gradient in SST (as represented by the IOD index) is closely associated with interannual rainfall variations in East Africa, particularly during the OND season (e.g., Black et al. 2003). While the life cycle of IOD events typically features maximum SST anomaly amplitudes in boreal fall (e.g., Saji et al. 1999), here Fig. 10 shows there is actually a close relationship between monthly climatological values of 


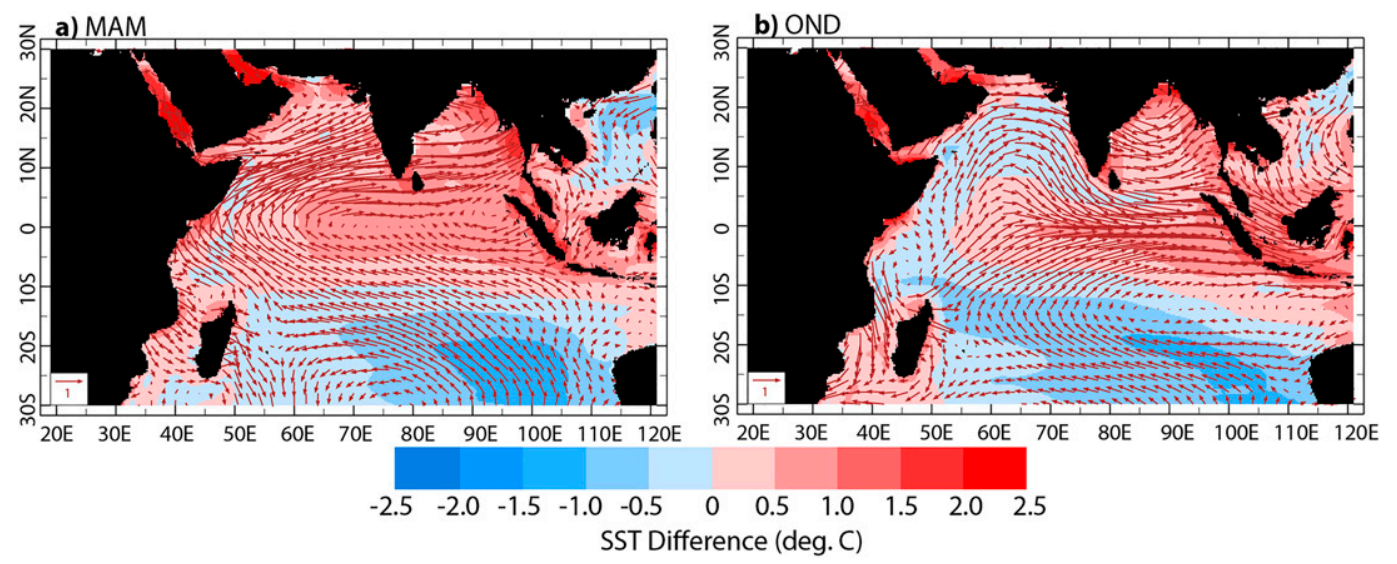

FIG. 9. Difference in CMIP5 climatological SST bias (shading) and 850-hPa wind (vectors; $\mathrm{m} \mathrm{s}^{-1}$ ) between four models with more realistic East African rainfall climatology and the remaining 27-model mean.

the IOD index and the annual cycle of East African rainfall. Note that for all panels in Fig. 10 the annual average values have been removed to emphasize the annual cycle. Figure 10a shows the annual cycle of the observed climatological (1979-2005) SST gradient based on the IOD index of Saji et al. (1999) along with the annual cycle of climatological East African rainfall. Variations in the SST gradient nicely follow the precipitation annual cycle, including peaks in both quantities during April and November and larger, positive values for MAM than OND. The temporal correlation between the two time series is $r=0.91$, which is highly statistically significant $(p<0.01)$ and greater than the correlation between western equatorial Indian Ocean SST $\left(10^{\circ} \mathrm{S}-10^{\circ} \mathrm{N}, 30^{\circ} \mathrm{E}-60^{\circ} \mathrm{E}\right)$ and rainfall $(r=0.64)$. Figure 10b shows the annual cycle of the climatological SST gradient for observations and for observations plus the CMIP5 31-model mean monthly SST bias. During the long rains season, the gradient for the observations plus bias case now peaks in May compared to April in observations. In addition, the zonal SST gradient is more strongly positive during OND for the bias case than for MAM. These results are quite consistent with the CMIP5 bias in East African rainfall, which is confirmed in Fig. 10c, where the temporal correlation between the two is shown to be $r=0.90$, which is statistically significant at $p<0.01$. It is noted that, while the zonal gradient in Indian Ocean SSTs based on observations plus CMIP5 biases shows a close connection to biases East African rainfall, the spatial patterns of these biases also reveal substantial seasonal variation, including important north-south asymmetries, as discussed earlier.

To examine changes in the annual cycle of tropospheric stability in relation to the CMIP5 bias in the annual cycle of East African precipitation, the MSE framework used in Seth et al. (2011) was employed. By definition, $\mathrm{MSE}=c_{p} T+L_{v} q+g Z$, where $c_{p}$ is the specific heat of air at constant pressure $\left(\mathrm{J} \mathrm{kg}^{-1} \mathrm{~K}^{-1}\right), L_{v}$ is the latent heat of vaporization $\left(\mathrm{J} \mathrm{kg}^{-1}\right), q$ is the specific humidity $\left(\mathrm{kg} \mathrm{kg}^{-1}\right), T$ is the atmospheric temperature $(\mathrm{K}), g$ is the acceleration of gravity $\left(\mathrm{m} \mathrm{s}^{-2}\right)$, and $Z$ is the geopotential height (gpm). Following Seth et al. (2011), to estimate the free tropospheric stability the difference in MSE between the upper troposphere $(200 \mathrm{hPa})$ and near surface $(850 \mathrm{hPa})$ was examined for monthly climatological values through the annual cycle. Given the very low specific humidity at $200 \mathrm{hPa}$, to a very close approximation the MSE was approximated as $\mathrm{MSE}_{200}=$ $c_{p} T+g Z$ and the vertical change in MSE thus computed as

$$
\delta \mathrm{MSE}=\mathrm{MSE}_{200}-\mathrm{MSE}_{850} .
$$

Figure 11 shows the annual cycle (annual mean removed) of $\delta$ MSE for the ECHAM5 bias and control runs evaluated over East Africa, where monthly values have been multiplied by -1 so that positive values are consistent with reduced static stability and greater precipitation. For the control runs, $\delta$ MSE peaks in April and is greater during MAM than in OND, which is consistent with the observed annual cycle of East African rainfall. For the ECHAM5 bias runs, $\delta \mathrm{MSE}$ peaks in May (exceeding control run values) with April values lower than in the control runs, consistent with the 1-month lag in the peak of the long rains in the bias runs (and CMIP5) relative to observations. While bias run values of $\delta \mathrm{MSE}$ for OND are not larger than those for MAM, the difference between the bias and control run values is. The temporal correlation between control (bias) run $\delta \mathrm{MSE}$ and observed (CMIP5) East African 

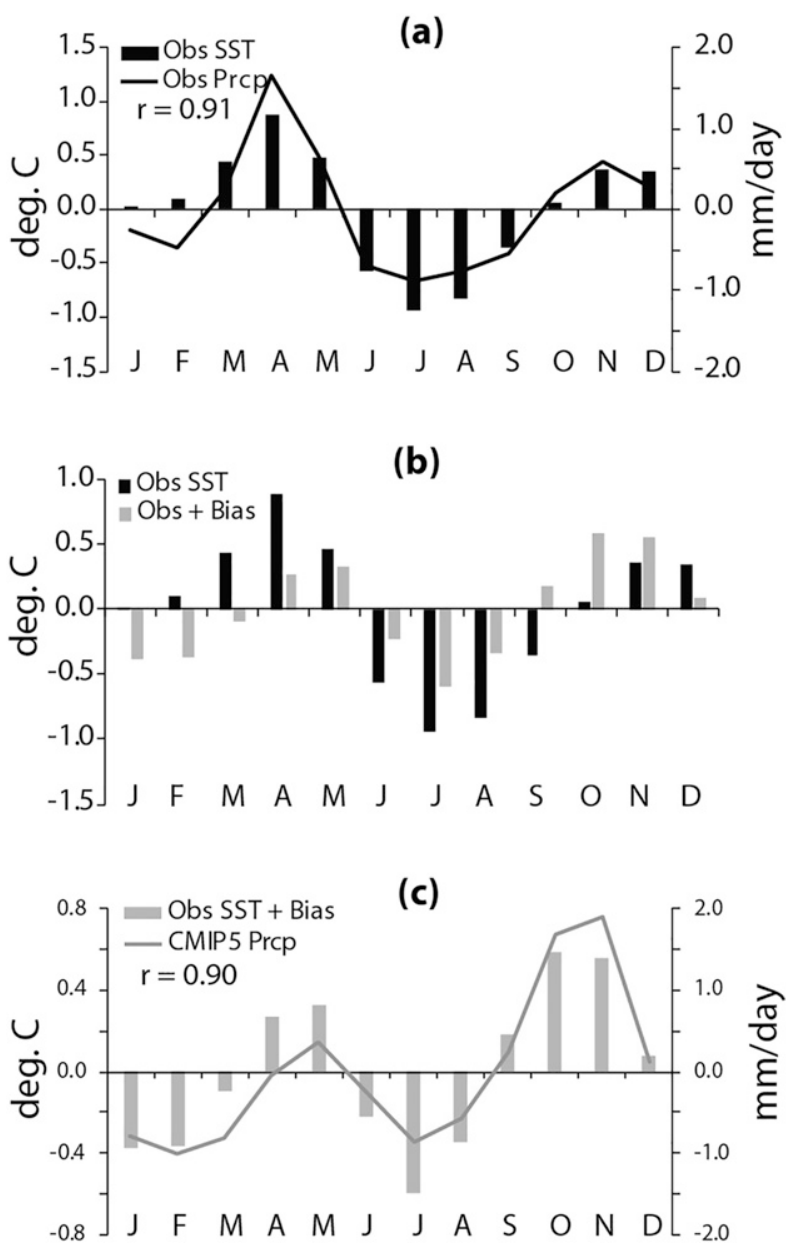

FIG. 10. (a) Monthly differences from the annual mean values of observed (GPCC) East African rainfall (black line; $\mathrm{mm} \mathrm{day}^{-1}$ ) and the zonal gradient in equatorial Indian Ocean SST (black bars; ${ }^{\circ} \mathrm{C}$ ). (b) As in (a), but just for the SST gradient in observations (black bar) and observations plus the 31-model mean CMIP5 SST bias. (c) As in (a), but just for the gradient in observed SST plus SST bias, with the multimodel mean CMIP5 climatological East African rainfall also shown. Correlations between plotted time series also shown in the upper left of (a) and (c).

climatological rainfall is $r=0.94(0.66)$, which are both statistically significant $(p<0.05)$, but clearly lower for the bias run case. For both the control and bias runs, the annual cycle of $\delta \mathrm{MSE}$ is dominated by changes in $\mathrm{MSE}_{850}$, and more specifically, by the specific humidity at $850 \mathrm{hPa}$ as shown in Figs. 11b and 11c. This is consistent with the findings of Yang et al. (2015a) in their evaluation of the annual cycle of observed East African rainfall.

In addition to stability, to capture changes in moisture transport and supply, the annual cycle of vertical column precipitable water (PWAT) was evaluated in the ECHAM5 bias and control runs. The monthly difference (bias - control) in climatological PWAT is shown in
Fig. 11d, where the annual mean has again been subtracted. The figure shows the PWAT differences for the MAM season are negative (the bias runs are comparatively dry) although for the month of May the difference is slightly positive, which is consistent with the CMIP5 rainfall bias for this season. For the OND season, the PWAT differences are much more strongly positive, which is consistent with the tendency for too much rainfall during this season in the ECHAM5 bias runs (and CMIP5).

Taken together, the ECHAM5 MSE and PWAT results are generally consistent with the CMIP5 climatological rainfall biases for East Africa. While consistent, it was desirable to further compare the MSE and PWAT results for ECHAM5 with those for the CMIP5 multimodel mean, as shown in Fig. 12. The figure shows the climatological annual cycles (annual mean removed) of $\delta$ MSE and PWAT over East Africa in the ECHAM5 bias runs and for the CMIP5 multimodel mean (data for only 28 of the 31 models was available). For both variables the annual cycles are very similar, with the temporal correlation between the ECHAM5 bias runs and CMIP5 model historical runs being $r=0.95$ for $\delta \mathrm{MSE}$ and $r=0.98$ for PWAT. Thus, the ECHAM5 is found to do a good job replicating the behavior of the CMIP5 models in this regard.

\section{Summary and conclusions}

Most CMIP5 coupled models fail to properly simulate the bimodal annual cycle of East African rainfall, tending to underestimate the MAM long rains and overestimate the OND short rains. The main goal of this study was to examine the extent to which these rainfall simulation errors are tied to biases in the climatological SST biases in the CMIP5 models. The approach was to first compute monthly climatological SST biases for 31 coupled models, which were found to be generally consistent across models for both the nearglobal domain $\left(50^{\circ} \mathrm{S}-50^{\circ} \mathrm{N}\right)$ and the Indian Ocean region $\left(25^{\circ} \mathrm{S}-25^{\circ} \mathrm{N}, 20^{\circ}-120^{\circ} \mathrm{E}\right)$. The multimodel mean, monthly SST biases for the near-global domain were then added to the observed, monthly SSTs, with this combined dataset used as the lower boundary forcing in the ECHAM5 atmospheric climate model. An ensemble of these bias runs was generated with output compared with a set of control runs generated by forcing ECHAM5 with observed monthly SSTs.

The ensemble mean of the ECHAM5 control runs was found to do a generally good job in capturing the observed, bimodal rainfall annual cycle in East Africa. The ensemble mean of the ECHAM5 bias runs, in turn, generally reproduced the spurious characteristics of that 

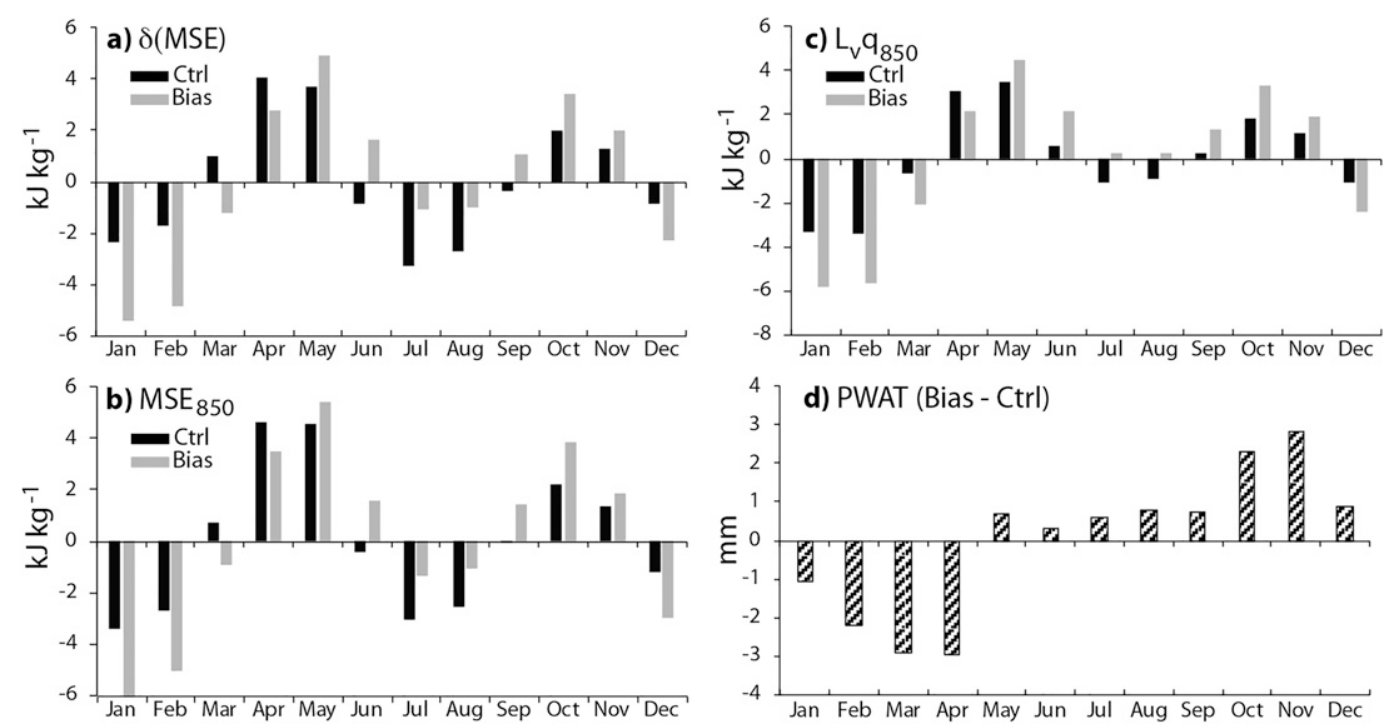

FIG. 11. Monthly departures from annual mean values of (a) climatological (1979-2005) $\delta \mathrm{MSE}\left(\mathrm{kJ} \mathrm{kg}^{-1}\right.$; multiplied by -1) values over East Africa in the ECHAM5 ensemble mean of the control runs (black bars) and bias runs (gray bars). (b) As in (a), but for just the MSE at $850 \mathrm{hPa}\left(\mathrm{kJ} \mathrm{kg}^{-1}\right)$. (c) As in (b), but just for the specific humidity contribution to MSE at $850 \mathrm{hPa}\left(\mathrm{kJ} \mathrm{kg}^{-1}\right)$. (d) Monthly departures from the annual mean value of climatological (1979-2005) PWAT (mm) over East Africa, plotted as the difference in ECHAM5 ensemble mean values (bias - control).

annual cycle as seen in the CMIP5 multimodel mean. This includes too little rainfall during the MAM long rains, a 1-month lag in the peak of the long rains relative to observations, and too much rainfall during the OND short rains season. Diagnostics of the regional low-level atmospheric circulation revealed that the ECHAM5 model response to the CMIP5 multimodel mean SST biases is an anomalous atmospheric circulation that opposes the observed climatological flow during MAM (and JJAS) and reinforces it during OND. These results are consistent with the decreased MAM rainfall, the delay in the peak of the long rains, and enhanced OND short rains seen in the bias runs and CMIP5 model climatologies. They are also consistent with the findings of Y15, who emphasized related behavior in a single coupled model and who further examined what mechanisms are associated with the generation of the climatological SST biases themselves.

Further diagnostics showed that the climatological annual cycle of East African rainfall is closely associated with the climatological zonal gradient in equatorial Indian Ocean SSTs. Further, when the annual cycle of this zonal gradient is computed for SSTs that include the CMIP5 multimodel mean SST bias, it is found to be closely related to the spurious annual cycle of East African rainfall identified in most CMIP5 models. This
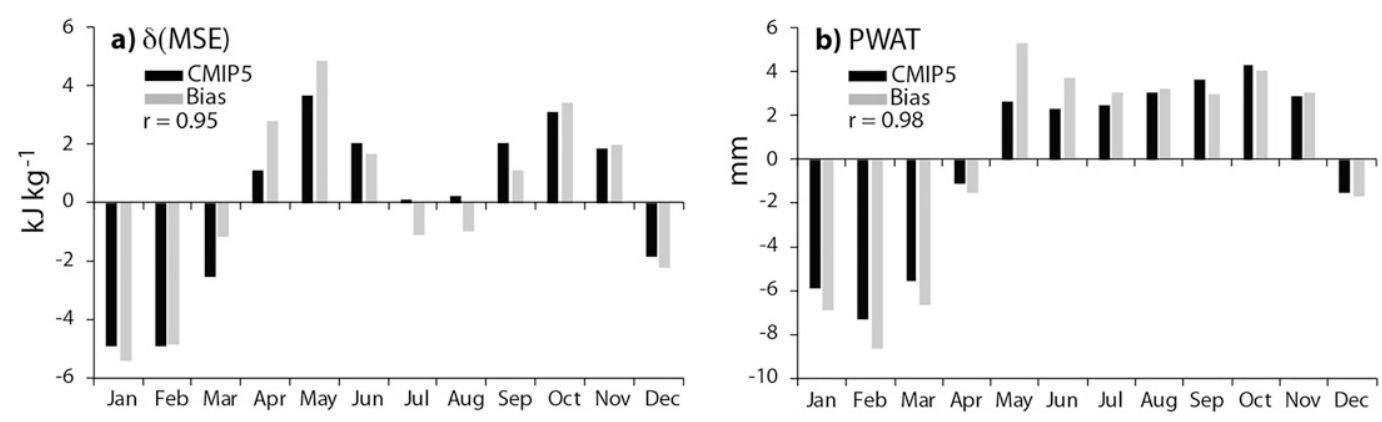

FIG. 12. (a) As in Fig. 11a, but for MSE differences $\left(\mathrm{kJ} \mathrm{kg}^{-1}\right.$ ) averaged across 28 CMIP5 models (black bars) and the ensemble mean of the ECHAM5 bias runs (gray bars). (b) As in Fig. 11d, but for the 31-model CMIP5 average PWAT (mm; black bars) and the ensemble mean of the ECHAM5 bias runs. Temporal correlations between time series also shown in the upper left of both panels. 
TABLE A1. List of the 31 CMIP5 models used in the study and their associated institutions.

\begin{tabular}{|c|c|c|}
\hline Model & Name & Institution \\
\hline 1 & ACCESS1.3 & $\begin{array}{l}\text { Australian Community Climate and Earth } \\
\text { System Simulator }\end{array}$ \\
\hline 2 & BCC-CSM1.1 & $\begin{array}{l}\text { Beijing Climate Center, China } \\
\text { Meteorological Administration }\end{array}$ \\
\hline 3 & BCC-CSM1-m & As above \\
\hline 4 & BNU-ESM & Beijing Normal University \\
\hline 5 & CanESM2 & $\begin{array}{l}\text { Canadian Centre for Climate Modeling } \\
\text { and Analysis }\end{array}$ \\
\hline 6 & CCSM4 & $\begin{array}{l}\text { National Center for Atmospheric } \\
\text { Research }\end{array}$ \\
\hline 7 & CESM1-BGC & $\begin{array}{l}\text { Community Earth System Model } \\
\text { Contributors }\end{array}$ \\
\hline 8 & CESM1-CAM5 & As above \\
\hline 9 & CESM1-CAM5.1-FV2 & As above \\
\hline 10 & CMCC-CESM & $\begin{array}{l}\text { Centro Euro-Mediterraneo per I } \\
\text { Cambiamenti Climatici }\end{array}$ \\
\hline 11 & CMCC-CMS & As above \\
\hline 12 & CNRM-CM5 & $\begin{array}{l}\text { Centre National de Recherches } \\
\text { Météorologiques }\end{array}$ \\
\hline 13 & CSIRO-Mk3.6.0 & $\begin{array}{l}\text { Commonwealth Scientific and Industrial } \\
\text { Research Organization }\end{array}$ \\
\hline 14 & FGOALS-g2 & LASG (Institute of Atmospheric Physics) \\
\hline 15 & FIO-ESM & The First Institute of Oceanography, SOA \\
\hline 16 & GFDL CM3 & $\begin{array}{l}\text { NOAA Geophysical Fluid Dynamics } \\
\text { Laboratory }\end{array}$ \\
\hline 17 & GFDL-ESM2M & As above \\
\hline 18 & GISS-E2-R & $\begin{array}{l}\text { NASA Goddard Institute for Space } \\
\text { Studies }\end{array}$ \\
\hline 19 & HadGEM2-CC & Met Office Hadley Centre \\
\hline 20 & HadGEM2-ES & As above \\
\hline 21 & INM-CM4 & Institute for Numerical Mathematics \\
\hline 22 & IPSL-CM5A-LR & Institut Pierre-Simon Laplace \\
\hline 23 & IPSL-CM5A-MR & As above \\
\hline 24 & IPSL-CM5B-LR & As above \\
\hline 25 & MIROC-ESM & $\begin{array}{l}\text { Japan Agency for Marine-Earth Science } \\
\text { and Technology, Atmosphere and } \\
\text { Ocean Research Institute, and National } \\
\text { Institute for Environmental Studies }\end{array}$ \\
\hline 26 & MIROC-ESM-CHEM & As above \\
\hline 27 & MIROC5 & As above \\
\hline 28 & MPI-ESM-LR & Max Planck Institute for Meteorology \\
\hline 29 & MPI-ESM-MR & As above \\
\hline 30 & MRI-CGCM3 & Meteorological Research Institute \\
\hline 31 & NorESM1-M & Norwegian Climate Center \\
\hline
\end{tabular}

zonal gradient pattern, in turn, was identified to be part of a larger SST bias pattern that includes a substantial north-south gradient in Indian Ocean SSTs during boreal spring with a more zonal pattern dominating from boreal summer into the fall.

Using a MSE framework, the annual cycle of static stability in the ECHAM5 control runs is found to be closely correlated with the observed annual cycle of East African rainfall $(r=0.94)$, being most closely associated with changes in low-level moisture. The annual cycle of stability in the ECHAM5 bias runs shows a weaker, although statistically significant, relationship to the annual cycle CMIP5 East African rainfall $(r=0.66)$. To capture the broader influence of moisture transport and supply on rainfall, an analysis of PWAT in ECHAM5 bias runs revealed that it is consistent with the spurious enhancement of OND rainfall seen in CMIP5 simulations, being anomalously high during this season compared to the control runs. In addition, the annual cycle of static stability and PWAT in the ECHAM5 bias runs was 
found to be strongly correlated with respective values obtained as the multimodel mean from CMIP5 simulations, indicating the ECHAM5 yields a realistic representation of CMIP5 coupled models in this regard.

Collectively, the results indicate that climatological SST biases in CMIP5 historical simulations play a fundamental role in the improper simulation of the East African rainfall climatology in those same models. As the atmospheric model is generally capable of simulating the annual cycle of East African rainfall when forced with the observed annual cycle of SSTs, this points to deficiencies in the ocean component of the CMIP5 coupled models. As such, these results have important implications for interpreting projections of East African rainfall under increasing greenhouse gas forcing. For example, it is clear that the annual cycle of East African rainfall is sensitive to seasonally varying spatial patterns of climatological SST. To the extent that coupled model biases in the SST mean state influence projected changes in SST, these biases may increase the uncertainty in regional climate projections (e.g., He and Soden 2016). Specific to East Africa, to the extent that projected changes in Indian Ocean SSTs are similar to important bias patterns in simulated SSTs in the current climate (e.g., Lyon and Vigaud 2017), confidence in those projections is diminished.

Acknowledgments. This work was supported by a grant from the National Science Foundation, Award AGS 1650037, which is gratefully acknowledged. Many of the calculations in this study were performed using computing and data storage resources at the International Research Institute's Data Library at Columbia University (http://iridl.ldeo.columbia.edu). The World Climate Research Programme's Working Group on Coupled Modelling is acknowledged, which is responsible for CMIP, and author thanks the climate modeling groups (listed in the appendix of this paper) for producing and making available their model output. For CMIP the U.S. Department of Energy's Program for Climate Model Diagnosis and Intercomparison provides coordinating support and led development of software infrastructure in partnership with the Global Organization for Earth System Science Portals. The author thanks two reviewers for their helpful comments that served to improve the original manuscript.

Data availability statement. The ECHAM5 model output used in this study is archived at the International Research Institute's Data Library at Columbia University and access can be granted upon request to the author. The CMIP5 data are available through the ESGF peer-to-peer (P2P) enterprise system (http://esgf-node.llnl.gov).

\section{APPENDIX}

\section{CMIP5 Models}

Table A1 lists the 31 CMIP5 models used in the study and the institution associated with each model.

\section{REFERENCES}

Ashouri, H., K. Hsu, S. Sorooshian, D. K. Braithwaite, K. R. Knapp, L. D. Cecil, B. R. Nelson, and O. P. Prat, 2015: PERSIANN-CDR: Daily precipitation climate data record from multisatellite observations for hydrological and climate studies. Bull. Amer. Meteor. Soc., 96, 69-83, https://doi.org/ 10.1175/BAMS-D-13-00068.1.

Black, E., J. Slingo, and K. R. Sperber, 2003: An observational study of the relationship between excessively strong short rains in coastal East Africa and Indian Ocean SST. Mon. Wea. Rev., 131, 74-94, https://doi.org/10.1175/1520-0493(2003) 131<0074:AOSOTR > 2.0.CO;2.

Bollasina, M. A., and Y. Ming, 2013: The general circulation model precipitation bias over the southwestern equatorial Indian Ocean and its implications for simulating the South Asian monsoon. Climate Dyn., 40, 823-838, https://doi.org/10.1007/ s00382-012-1347-7.

Cai, W., X.-T. Zheng, E. Weller, M. Collins, T. Cowan, M. Lengaigne, W. Yu, and T. Yamagata, 2013: Projected response of the Indian Ocean dipole to greenhouse warming. Nat. Geosci., 6, 999-1007, https://doi.org/10.1038/ngeo2009.

Findlater, J., 1969: A major low-level air current near the Indian Ocean during the northern summer. Quart. J. Roy. Meteor. Soc., 95, 362-380, https://doi.org/10.1002/qj.49709540409.

Funk, C. P., and Coauthors, 2015: The Climate Hazards Infrared Precipitation with Stations-A new environmental record for monitoring extremes. Sci. Data, 2, 150066, https://doi.org/ 10.1038/sdata.2015.66.

Harris, I. C., and P. D. Jones, 2017: CRU TS4.01: Climatic Research Unit (CRU) Time-Series (TS) version 4.01 of highresolution gridded data of month-by-month variation in climate (Jan. 1901-Dec. 2016). Centre for Environmental Data Analysis, accessed 22 June 2020, http://catalogue.ceda.ac.uk/ uuid/58a8802721c94c66ae45c3baa4d814d0.

Hart, J. E., 1977: On the theory of the East African low level jet stream. Pure Appl. Geophys., 115, 1263-1282, https://doi.org/ 10.1007/BF00874409.

He, J., and B. J. Soden, 2016: The impact of SST biases on projections of anthropogenic climate change: A greater role for atmosphere-only models? Geophys. Res. Lett., 43, 7745-7750, https://doi.org/10.1002/2016GL069803.

Hession, S. L., and N. Moore, 2011: A spatial regression analysis of the influence of topography on monthly rainfall in East Africa. Int. J. Climatol., 31, 1440-1456, https://doi.org/10.1002/joc.2174.

Huang, B., and Coauthors, 2015: Extended Reconstructed Sea Surface Temperature version 4 (ERSST.v4). Part I: Upgrades and intercomparisons. J. Climate, 28, 911-930, https://doi.org/ 10.1175/JCLI-D-14-00006.1.

Huffman, G. J., R. F. Adler, D. T. Bolvin, and G. Gu, 2009: Improving the global precipitation record: GPCP version 2.1. Geophys. Res. Lett., 36, L17808, https://doi.org/10.1029/ 2009GL040000.

Hurrell, J. W., J. Hack, D. Shea, J. Caron, and J. Rosinski, 2008: A new sea surface temperature and sea ice boundary dataset for 
the Community Atmosphere Model. J. Climate, 21, 51455153, https://doi.org/10.1175/2008JCLI2292.1.

Li, G., and S.-P. Xie, 2012: Origins of tropical-wide SST biases in CMIP multi-model ensembles. Geophys. Res. Lett., 39, L22703, https://doi.org/10.1029/2012GL053777.

—, and - 2014: Tropical biases in CMIP5 multimodel ensemble: The excessive equatorial Pacific cold tongue and double ITCZ problems. J. Climate, 27, 1765-1780, https:// doi.org/10.1175/JCLI-D-13-00337.1.

Liebmann, B., and Coauthors, 2014: Understanding recent eastern Horn of Africa rainfall variability and change. J. Climate, 27, 8630-8645, https://doi.org/10.1175/JCLI-D-13-00714.1.

Lyon, B., 2014: Seasonal drought in the greater Horn of Africa and its recent increase during the March-May long rains. J. Climate, 27, 7953-7975, https://doi.org/10.1175/JCLI-D-1300459.1.

_- and N. Vigaud, 2017: Unraveling East Africa's climate paradox. Climate Extremes: Patterns and Mechanisms, S.-Y. S. Wang et al., Eds., Wiley, 265-281.

Nicholson, S. E., 1996: A review of climate dynamics and climate variability in the Greater Horn. The Limnology, Climatology, and Paleoclimatology of the East African Lakes, T. C. Johnson and E. O. Odada, Eds., Gordon and Breach, 24-56.

Otieno, V. O., and R. O. Anyah, 2013: CMIP5 simulated climate conditions of the Greater Horn of Africa (GHA). Part I: Contemporary climate. Climate Dyn., 41, 2081-2097, https:// doi.org/10.1007/s00382-012-1549-z.

Rayner, N., D. Parker, E. Horton, C. Folland, L. Alexander, D. Rowell, E. Kent, and A. Kaplan, 2003: Global analyses of sea surface temperature, sea ice, and night marine air temperature since the late nineteenth century. J. Geophys. Res., 108, 4407, https://doi.org/10.1029/2002JD002670.

Reynolds, R. W., N. Rayner, T. Smith, D. Stokes, and W. Wang, 2002: An improved in situ and satellite SST analysis for climate. J. Climate, 15, 1609-1625, https://doi.org/10.1175/15200442(2002)015<1609:AIISAS > 2.0.CO;2.

Richter, I., S.-P. Xie, S. K. Behera, T. Doi, and Y. Masumoto, 2014: Equatorial Atlantic variability and its relation to mean state biases in CMIP5. Climate Dyn., 42, 171-188, https://doi.org/ 10.1007/s00382-012-1624-5.

Riddle, E. E., and K. H. Cook, 2008: Abrupt rainfall transitions over the Greater Horn of Africa: Observations and regional model simulations. J. Geophys. Res., 113, D15109, https:// doi.org/10.1029/2007JD009202.

Roeckner, E., and Coauthors, 2003: The atmospheric general circulation model ECHAM5. Part I: Model description. Max Planck Institute for Meteorology Rep. 349, 140 pp., https://
www.mpimet.mpg.de/fileadmin/publikationen/Reports/max scirep_349.pdf.

Rudolf, B., and F. Rubel, 2005: Global precipitation. Observed Global Climate, M. Hantel, Ed., Landolt-Börnstein: Numerical Data and Functional Relationships in Science and Technology Series, Vol. 6, Springer, 11.1-11.53.

Saji, N. H., B. N. Goswami, P. N. Vinayachandran, and T. Yamagata, 1999: A dipole mode in the tropical Indian Ocean. Nature, 401, 360-363, https://doi.org/10.1038/43854.

Seth, A., S. A. Rauscher, M. Rojas, A. Giannini, and S. J. Camargo, 2011: Enhanced spring convective barrier for monsoons in a warmer world? Climatic Change, 104, 403-414, https://doi.org/ 10.1007/s10584-010-9973-8.

Simmons, A., and D. M. Burridge, 1981: An energy and angular momentum conserving vertical finite difference scheme and hybrid vertical coordinates. Mon. Wea. Rev., 109, 758-766, https://doi.org/10.1175/1520-0493(1981)109<0758:AEAAMC> 2.0.CO;2.

Taylor, K. E., R. J. Stouffer, and G. A. Meehl, 2012: An overview of CMIP5 and the experiment design. Bull. Amer. Meteor. Soc., 93, 485-498, https://doi.org/10.1175/BAMS-D-11-00094.1.

Tozuka, T., T. Doi, T. Miyasaka, N. Keenlyside, and T. Yamagata, 2011: Key factors in simulating the equatorial Atlantic zonal sea surface temperature gradient in a coupled general circulation model. J. Geophys. Res., 116, C06010, https://doi.org/ 10.1029/2010JC006717.

Vigaud, N., B. Lyon, and D. E. Lee, 2020: Subseasonal convection variability over the Intra-American Seas simulated by an AGCM and sensitivity to CMIP5 SST biases and projections. Int. J. Climatol., 40, 4556-4574, https://doi.org/10.1002/joc.6475.

Vizy, E. K., and K. H. Cook, 2003: Connections between the summer East African and Indian rainfall regimes. J. Geophys. Res., 108, 4510, https://doi.org/10.1029/2003JD003452.

Xie, P., and P. A. Arkin, 1997: Global precipitation: A 17-year monthly analysis based on gauge observations, satellite estimates, and numerical model outputs. Bull. Amer. Meteor. Soc., 78, 2539-2558, https://doi.org/ 10.1175/1520-0477(1997)078<2539:GPAYMA>2.0.CO;2.

Xu, Z., P. Chang, I. Richter, W. Kim, and G. Tang, 2014: Diagnosing southeast tropical Atlantic SST and ocean circulation biases in the CMIP5 ensemble. Climate Dyn., 43, 31233145, https://doi.org/10.1007/s00382-014-2247-9.

Yang, W., R. Seager, M. A. Cane, and B. Lyon, 2015a: The annual cycle of East African precipitation. J. Climate, 28, 2385-2404, https://doi.org/10.1175/JCLI-D-14-00484.1.

$-, \ldots,-$, and $-2015 \mathrm{~b}$ : The rainfall annual cycle bias over East Africa in CMIP5 coupled climate models. J. Climate, 28, 9789-9802, https://doi.org/10.1175/JCLI-D-15-0323.1. 